\title{
BCL10 wt Allele
}

National Cancer Institute

\section{Source}

National Cancer Institute. BCL10 wt Allele. NCI Thesaurus. Code C49369.

Human BCL10 wild-type allele is located in the vicinity of $1 \mathrm{p} 22$ and is approximately $12 \mathrm{~kb}$ in length. This allele, which encodes B-cell lymphoma/leukemia 10 protein, is involved in the induction of apoptosis and the activation of NF-kappaB. 